\title{
AN EXAMPLE OF MENINGIOMATOUS HYPEROSTOSIS FROM MEDIEVAL ROCHESTER
}

\author{
by \\ T. ANDERSON *
}

INTRODUCTION

At the invitation of the Dean and Chapter of Rochester Cathedral, the Canterbury Archaeological Trust carried out an excavation within the Lay cemetery of the Cathedral during April and May 1990. This project, funded by the Cathedral authorities, was undertaken before work began on the consolidation of the foundations of the Chair Store, which is situated between the west side of the north transept and the north side of the nave (fig. 1). The excavation consisted of three small trenches (marked A, B and C) each $3 \mathrm{~m} \times 1 \mathrm{~m}$, and up to $4.5 \mathrm{~m}$ deep.

THE EXCAVATION

The area was excavated down to natural brickearth, and several features were identified below the cemetery deposits. The earliest were a gully (numbered 98 on fig. 1) and a shallow pit (no. 96), the latter with Belgic pottery of the early first century AD. Roman pottery was found in three other pits (nos. 90, 94 and 100). No. 94 contained grey/green silt and was probably a cess pit; its upper level was filled with burnt clay (daub) and ash. No Anglo-Saxon deposits were discovered. Sixty-three burials were excavated ranging in date from the early middle ages to the midnineteenth century.

The occurrence of several pits suggests that the area was open ground during the earlier Roman period. The daub recovered from no. 94 may have been derived from a nearby timber building. Occupation during the later Roman period (fourth century AD) is implied by the pottery assemblage. In the small area excavated, there was no evidence for settlement during the Anglo-Saxon period. A residual sherd of seventh-century organic-tempered pottery was found in a medieval grave.

The earliest literary reference to the Lay cemetery dates to $1418,{ }^{1}$ although it was probably in use long before this time, perhaps even before the Norman conquest since the Cathedral was founded in $\mathrm{AD}$ 604. It is known that a churchyard wall and gate were contracted for in 1627. During the early half of the nineteenth century, the walled area was raised by about a metre so that more burials could be accommodated. A new

* T. Anderson, Resident Osteo-archaeologist Canterbury Archaeological Trust, 92A Broad Street, Canterbury, Kent, CT1 2LU

\footnotetext{
${ }^{1}$ Alan Ward and Trevor Anderson, 'Excavations at Rochester Cathedral', Arch. Cant., 1990, 108: 91-152, p. 96 .
} 


\section{T. Anderson}

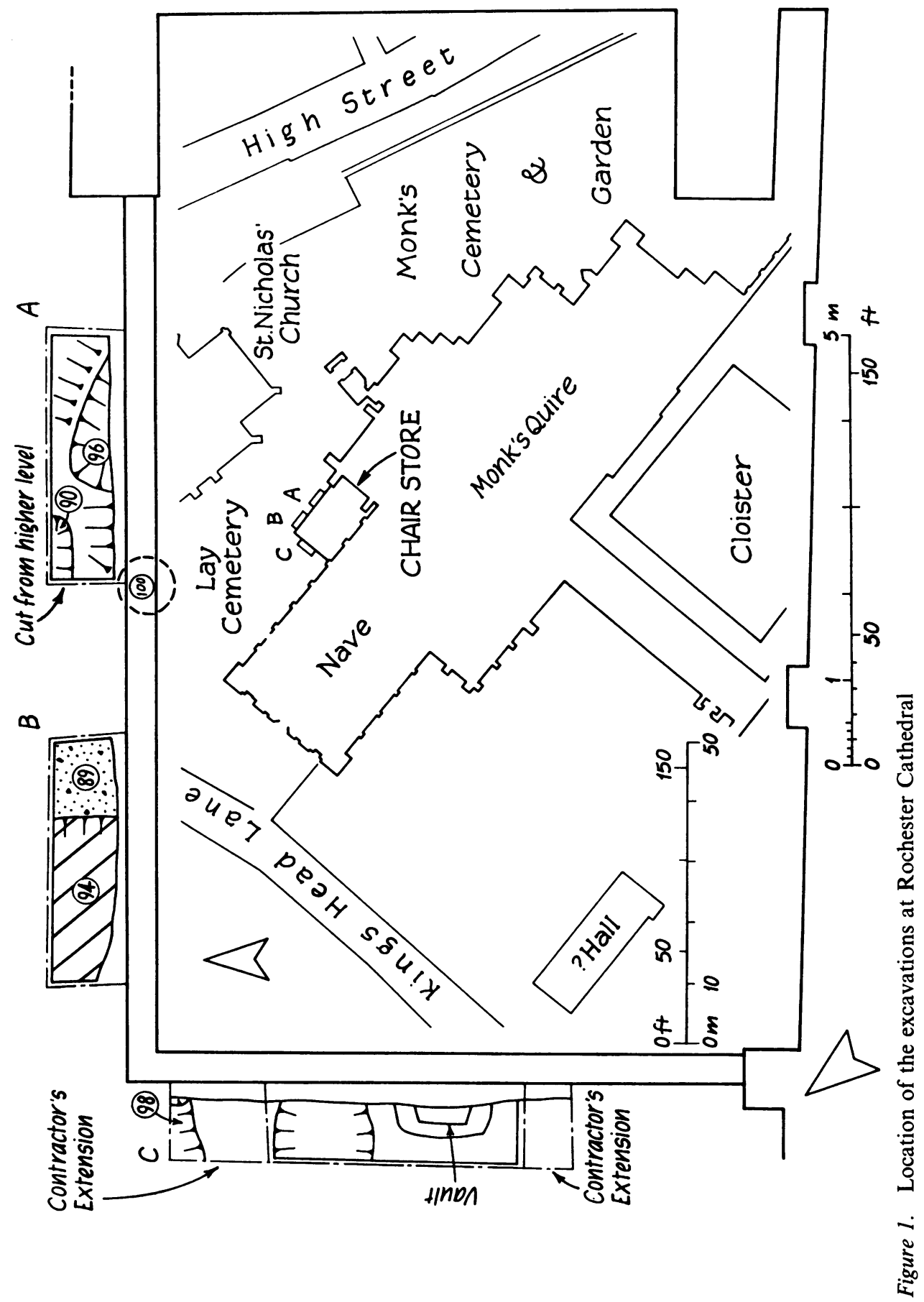






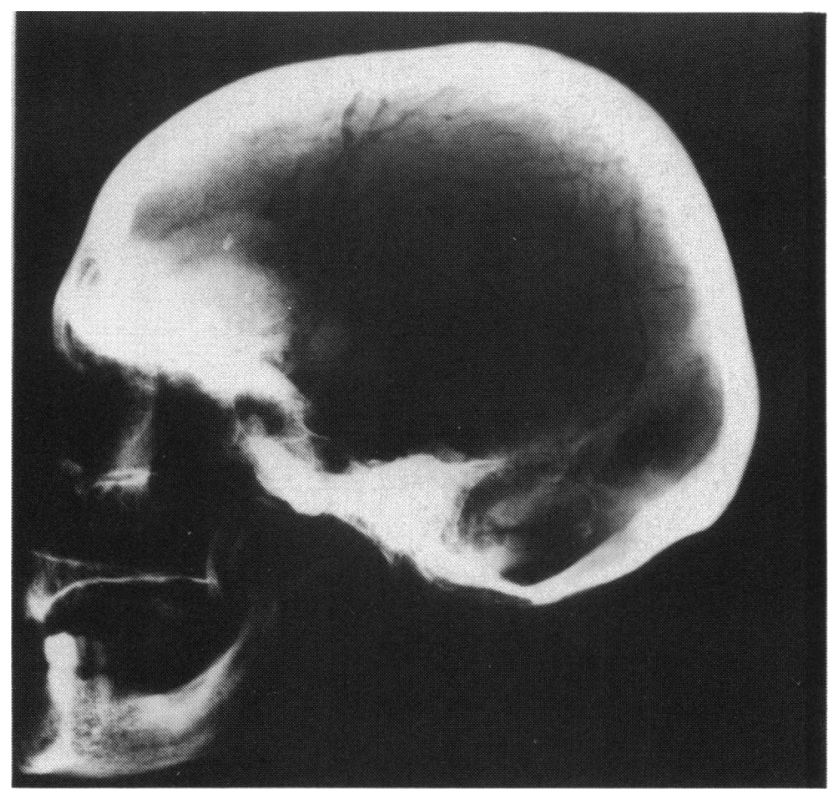

Plate 3 SK46. Skull: Radiograph, lateral projection.

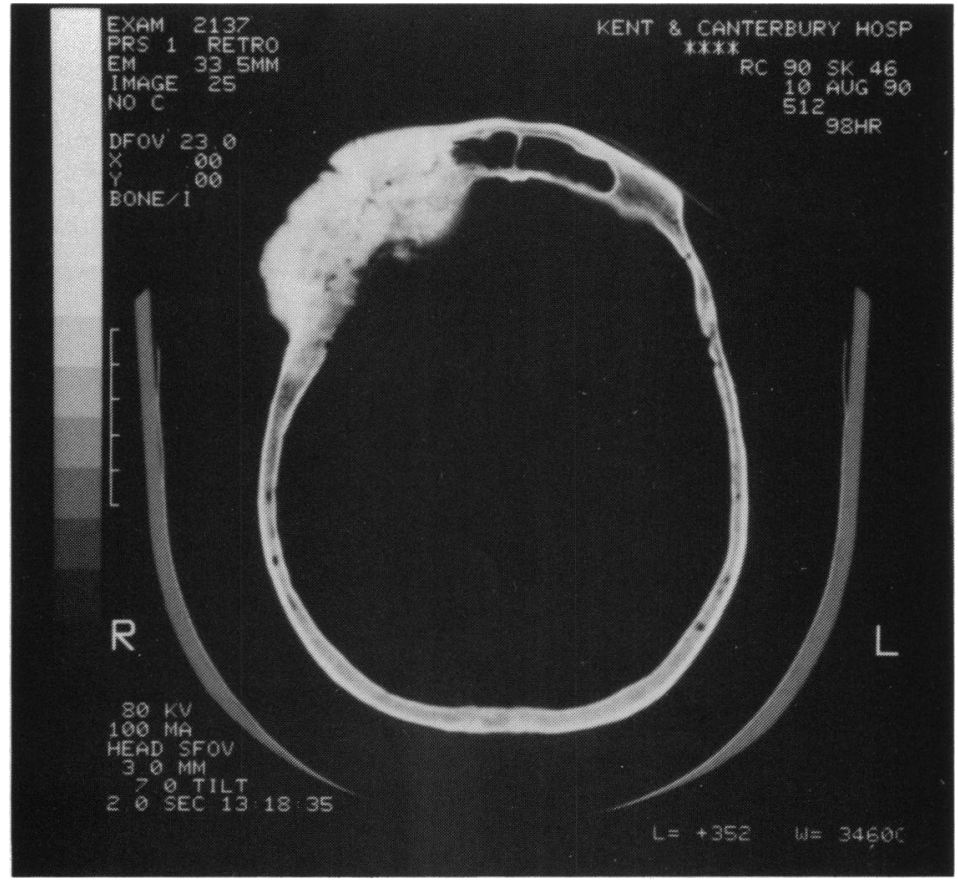

Plate 4 SK46. Skull: CT scan. Scanner used for the examination was an I.G.E. CT 9800 "Hilight". The skull was placed in the head support of the scanner table and supported with radio-lucent pads. Adjustment of the skull was made so that it was in the "supine" position with the orbito-meatal line $90^{\circ}$ to the horizontal. Scanning was performed parallel to the orbitomeatal line from lower orbital margin to the cranial vertex. 
cemetery was opened on the outskirts of the city in the mid-nineteenth century and the Lay cemetery went out of general use by $1875 .^{2}$

\section{THE SKELETAL MATERIAL}

The purpose of this paper is to examine in greater detail the remains of a medieval skeleton which displays osseous alteration secondary to an intracranial meningioma.

The skeleton in question, SK 46, is about 50 per cent complete. The skull is intact; most of the long bones are represented by damaged diaphyses; only small pelvic fragments were recovered and most of the spine and ribs are missing, but the hands and feet are well represented. Recognized ageing and sexing techniques ${ }^{3}$ suggest that the fragmentary remains are from a female who was between 35-50 years old. Following the formulae of Trotter and Gleser ${ }^{4}$ the right tibia, the only complete long

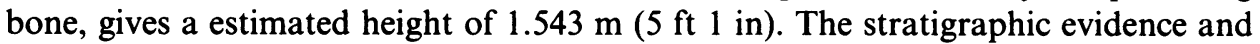
the associated finds suggest a fifteenth-, or possibly late fourteenth-century date of burial.

The extra-cranial skeleton was examined radiologically but no anomalies were discovered. The dry bones show that the individual was suffering from marked joint degeneration of the spine. The available diarthrodial joints (CV7-TV6) display advanced arthritic alteration. Fragmentary vertebral bodies show marked porosity, evidence of disc degeneration. Oral health was of low standard. All molars, except the second right maxillary, all first premolars, except the right mandibular, were lost during life. Six maxillary teeth were lost post-mortem. The remaining dentition, although free from caries, was heavily encrusted with tartar.

The most obvious bone pathology affecting SK46 is the large bony overgrowth on the right frontal bone. The hyperostosis consists of a massive ovoid overgrowth of spongy bone. It has encroached upon the spheno-temporal articulation and has obliterated the pteric portion of the coronal suture (plate 1). From the suture, it extends to the supero-lateral margin of the orbit, a distance of $65 \mathrm{~mm}$. Its height, from the greater wing of the sphenoid to its upper extremity on the frontal bone, is $63 \mathrm{~mm}$. The ovoid overgrowth is regular and clearly demarcated (plate 1), with a circumference of $125 \mathrm{~mm}$. The lesion has caused a swelling which stands proud of the frontal bone by $45 \mathrm{~mm}$ (plate 2 ).

The hyperostosis has spread into the zygomatic bone, causing marked swelling and porosity (plate 1). Comparison with the normal left orbit shows quite clearly bony overgrowth in all but the infero-medial aspect of the right eye socket. In the sphenoid bone, just below the spongy hyperostosis, there is a circular ragged-edged defect

\footnotetext{
${ }^{2}$ Ward and Anderson, op. cit., note 1 above, p. 97. This information was kindly provided by the site director, Alan Ward. See note 1 above for the complete excavation report which includes a detailed osteological analysis.

${ }^{3}$ Ibid., pp. 130-2.

${ }^{4}$ Mildred Trotter and G. C. Gleser, 'Estimation of stature from long bones of American Whites and Negroes', Am. J. Phys. Anthropol., 1952, 10: 463-514, Table 5; idem, 'A re-evaluation of estimation of stature based on measurements of stature taken during life and long bones after death', ibid., 1958, 16: 79-123, Table 12.
} 


\section{T. Anderson}

(c. $10 \mathrm{~mm}$ in diameter), penetrating to the inner table. The bone in the vicinity of the defect is roughened and irregular in nature.

\section{DIAGNOSIS}

Based on the morphology and location of the lesion as well as the age and sex of the "patient", the most plausible diagnosis is one of meningiomatous hyperostosis. The bony outgrowth is a pathological response to the initial soft tissue lesion and is not in itself tumorous. ${ }^{5}$ Such hyperostoses have been reported to occur in 20 to 25 per cent of meningiomas. ${ }^{6}$ The sphenoidal defect suggests a malignant tendency; however it could represent part of the destructive process of an advanced meningioma. ${ }^{7}$

The chronicity of the hyperostosis, evidenced by its smooth, well-defined edges, as well as the dense nature of the overgrowth, negates a primary malignant neoplasm, such as osteosarcoma. The latter rarely occur after the age of 25 and do not normally present on the cranium. ${ }^{8}$ There is no evidence of Paget's disease in any of the bones (this is not surprising, in view of the age and sex of the skeleton). Consequently a cranial Pagetic osteosarcoma can be ruled out. The X-ray findings ${ }^{9}$ do not display the "sun-burst" appearance of an osteosarcoma; rather they suggest a chronic, slowgrowing lesion (plate 3).

A differential diagnosis of haemangioma must be considered. The latter, an overgrowth of vascular channels, may be indistinguishable from a meningiomatous hyperostosis in dry bone material. Haemangiomas most commonly involve the spine, but they frequently present on the cranium, favouring the parietal and the frontal bones. ${ }^{10}$ The X-ray evidence is however more suggestive of a meningioma since the peripheral lytic margin, ${ }^{11}$ common in haemangiomas, is absent (plate 3). CT scans ${ }^{12}$ clearly show destruction of the inner table (plate 4), which is characteristic of an intracranial meningioma. ${ }^{13}$

Fibrous dysplasia, internal frontal hyperostosis (Morgagni-Morel syndrome), Paget's disease, and leontiasis ossea can cause thickening of the skull. However, all of these diseases would result in quite a different picture to that presented by SK46. Monostotic fibrous dysplasia occurs most frequently in the leg bones and in the ribs. ${ }^{14}$ If the skull is affected, the cranial base and the facial bones are the preferred sites. ${ }^{15}$ Internal frontal hyperostosis is most frequently diagnosed in post-menopausal women. As the term suggests, the new bone growth is, unlike SK46, restricted to the

\footnotetext{
${ }^{5}$ Harvey Cushing, 'The meningiomas (dural endotheliomas): their source, and favoured seats of origin', Brain, 1922, 45: 282-316, pp. 304-5; R. Ted Steinbock, Paleopathological diagnosis and interpretation: bone diseases in ancient human populations, Springfield, C.C. Thomas, 1976, p. 353.

${ }^{6}$ G. F. Rowbotham, 'The hyperostoses in relation with the meningiomas', Br. J. Surg., 1939, 26: 593-623, p. 595; Sir John Walton (ed), Brain's disease of the nervous system, Oxford University Press, 1985, p. 148.

${ }^{7}$ Dr Adrian Carter, personal communication.

${ }^{8}$ Steinbock, op.cit., note 5 above, p. 354.

${ }^{9}$ Kindly provided by the Department of Radiography, Christ Church College, Canterbury.

${ }^{10}$ Steinbock, op. cit., note 5 above, p. 351 .

${ }^{11}$ Donald J. Ortner and Walter G. J. Putschar, Identification of pathological conditions in human skeletal remains, Washington, Smithsonian Institution Press, Contributions to Anthropology, No. 28, 1985, p. 377.

${ }^{12}$ Kindly provided by Jon Billings. Superintendent CT Radiographer, Kent and Canterbury Hospital.

13 Ortner and Putschar, op. cit., note 11 above, p. 378.

${ }^{14}$ Steinbock, op, cit., note 5 above, p.337.

15 Ortner and Putschar, op. cit., note 11 above, p. 317.
} 


\section{An example of meningiomatous hyperostosis}

endocranial surface of the frontal bone. ${ }^{16}$ In both Paget's disease and the rarer leontiasis ossea, excessive bone growth tends to involve most of the skull, rather than being restricted to a single hyperostotic lesion. ${ }^{17}$

Thus, SK46 displays osteological evidence, which, coupled with X-ray investigation and CT scan, supports a diagnosis of meningiomatous hyperostosis. This is a very rare finding in archaeologically retrieved remains.

Meningiomatous hyperostoses are known to be slow, but variable, in development. The overgrowth of SK46 is similar in size to a modern clinical example of 6 years duration. ${ }^{18}$ An example in the Royal College of Surgeons Museum (N9. 2) is larger, and yet it has developed over the same period of time. ${ }^{19}$ Consequently, it is not really possible to establish the chronicity of the meningioma in SK46. Apart from the disfigurement of the forehead and face, we can be confident that this unfortunate medieval woman suffered from unilateral exophthalmos. No doubt, compression of the optic nerve had led to loss of sight in the right eye. It is possible, but not certain, that increased intracranial pressure may have caused total blindness. ${ }^{20}$ It is impossible to obtain a clinical picture from a skeleton. The lytic defect in the greater wing of the sphenoid and the roughened surrounding bone may represent an aggressive, malignant neoplastic reaction. If the latter diagnosis is correct, this has established the cause of death for a medieval "patient" after an interval of 600 years.

\section{PALAEOPATHOLOGICAL EVIDENCE}

A review of the palaeopathological literature has shown that only 8 convincing examples of meningiomatous hyperostosis have been recovered from archaeological excavations throughout the world (table 1). Prior to this report only one example was known from Great Britain. This was unearthed at Radley in Oxfordshire and was dated to the Roman period. ${ }^{21}$ The earliest example is from Helouan in Upper Egypt and is dated to c. $3400 \mathrm{BC}^{22}$ However, recent examination of the skull has suggested a differential diagnosis of osteoangioma or haemangioma. ${ }^{23}$ It is very possible that the true incidence of meningiomatous hyperostosis is under-represented in dry bone studies due to mis-diagnosis. Also, examples without external bony overgrowth (i.e. 75 to 80 per cent of meningiomas) would not be recognized because the expense of $\mathrm{X}$-raying outwardly normal skulls would be prohibitive to archaeological units.

\footnotetext{
16 Ibid., p. 294.

17 Ibid., p. 311.

18 Ibid., plates $607-8$.

19 William Stokes, 'Ossifying sarcoma of the skull', Acad. med. Ireland., 1884, 2: 452-5, p. 452.

${ }^{20}$ Louis Bakay, 'Cruveilhier on meningiomas (1829-42)', Surg. Neurol., 1989, 32: 159-64, p. 159.

${ }^{21}$ Don Brothwell, 'The evidence for neoplasms', in Don Brothwell and A. T. Sandison (eds), Diseases in antiquity, Springfield, C. C. Thomas, 1967, pp. 320-45, on pp. 327, 332.

${ }_{22}$ Lambert Rogers, 'Meningiomas in Pharaoh's people', Br. J. Surg., 1949, 36: 423-4, Figs. 573-4.

${ }^{23}$ W. M. Pahl, 'Tumours of bone and soft tissue in ancient Egypt and Nubia: a synopsis of the detected cases', Int. J. Anthropol., 1986, 1: 267-76, p. 269.
} 


\section{T. Anderson}

Table 1: PALAEOPATHOLOGICAL EXAMPLES OF MENINGIOMATOUS HYPEROSTOSIS

\begin{tabular}{llll}
\hline Date & Sex & Age & Location \\
\hline I Dyn & M & $40-60$ & Helouan, Upper Egypt \\
XX DYN & M & $50-70$ & Meydun, Upper Egypt \\
Pre Contact & F & "middle age" & Chavina, Peru26 \\
Pre Contact & M & "elderly" & Paucarcancha, Peru27 $^{27}$ \\
Pre Contact & M & adult & Chicama, Peru \\
Pre Contact & M & "past middle age" & St Nicholas Is, California29 \\
Roman & F & adult & Radley, Oxfordshire \\
Medieval & F & $35-50$ & Present case
\end{tabular}

\section{HISTORICAL REVIEW}

The earliest literary reference to an apparent meningioma is Felix Platter's description in 1614 of a round acorn-like tumour formed on the brain's surface. Apparently this meningioma was aggressive: it caused severe neurological problems and death occurred two years after the onset of symptoms:

Caspar Bonecurtius, a noble knight, began to lose his mind gradually over a two year period, to such an extent that finally he was completely stupefied and did nothing rationally. He had no desire for food and ate only when forcibly fed. He went to bed only when compelled, and sat at a table resting on his arms and sleeping almost all the time. He spoke only when questioned and frequently prodded, and even then his words were few and had little relevance. All the while watery mucous dropped copiously and frequently from his nostrils. Finally after matters had gone on thus for six months, he died. ${ }^{31}$

This predates the earliest example reported by Cushing and Eisenhardt ${ }^{32}$ by almost 130 years. The latter involved a 34-year-old Prussian soldier and was first mentioned by Kaufman in 1743. According to Bakay, ${ }^{33}$ Antoine Louis managed to discover 20 cases of "tumeurs fongeuses de la dure-mère" predating 1774. However, some of these were possibly the result of metastatic carcinoma, tertiary syphilis or osteomyelitis.

24 See note 22.

25 Ibid., Figs. 575-7.

${ }^{26}$ Roy L. Moodie, 'Studies in paleopathology XVIII. Tumors of the head among pre-Columbian Peruvians', Ann. med. Hist., 1926, 8: 394-412, Figs. 2, 3; Kenneth H. Abbott and Cyril B. Courville, 'Historical notes on the meningiomas. I. A study of the hyperostoses in prehistoric skulls', Bull. Los Angeles Neurol. Soc., 1939, 4: 101-13, Figs. 1-3; Steinbock. op. cit., note 5 above, Fig. 141; Rose A. Tyson and Elizabeth S. Dyer Alcauskas (eds), Catalogue of the Hrdlička paleopathology collection, San Diego, San Diego Museum of Man, 1980, p. 45, Figs. E-G.

${ }^{2}$ George C. MacCurdy, 'Human skeletal remains from the highlands of Peru', Am. J. Phys. Anthropol., 1923, 6: 217-330, p. 264; Moodie, op. cit., note 26 above, Fig. 10; M. O. Zariquiey, 'Magicians and meningiomas', Med. Radiog. Photog., 1958, 34: 70- 2; Brothwell, op. cit., note 21 above, Fig. 3b; Steinbock, op. cit., note 5 above, Fig. 140.

${ }_{28}$ Moodie, op. cit., note 26 above, pp. $400-1$.

29 Abbott and Courville, op. cit., note 26 above, Figs 4-6.

30 Brothwell, op. cit., note 21 above, Fig. 6c.

${ }^{31}$ Martin G. Netsky and Jean Lapresle, 'The first account of a meningioma', Bull. Hist Med., 1956, 30: 465-8, p. 466.

32 Harvey Cushing and Louise Eisenhardt, The meningiomas: their classification, regional behaviour, life history, and surgical end results, Springfield, C. C. Thomas, 1938, Chapter XXI.

${ }^{33}$ See note 20 . 


\section{CONCLUSION}

The age and sex of SK46 are compatible with a diagnosis of meningioma. Although it cannot be proved, it is possible that the tumour was the rarer en plaque type, which is known to be commoner in the frontal and temporal regions ${ }^{34}$ and is reported to favour hyperostosis. ${ }^{35}$ The small stature, the advanced spinal degeneration and the poor state of oral hygiene lead us to suspect that this medieval woman was a member of the lower social class, engaged in heavy manual work. If this speculation is correct, it is in agreement with Preston-Martin's findings ${ }^{36}$ that meningiomas are more common in the lower social classes.

An unusual palaeopathological example of cranial overgrowth has been presented. Examination of the dry bone specimen, coupled with X-ray investigation and CT scan, support a diagnosis of meningiomatous hyperostosis. The age and sex of the skeleton conform to what is known from modern day meningioma patients. This is a rare find, bringing the number of convincing cases reported in world literature to only 8 (table 1). In the presented example from later medieval Rochester, there is evidence of cranial disfigurement, notably exophthalmos and possible blindness. There is a distinct possibility that the meningioma had developed an aggressive malignant tendency. If this is correct, it permits diagnosis of cause of death of some 600 years after burial.

\footnotetext{
${ }^{34}$ D. B. Phemister, 'The nature of cranial hyperostosis overlying endothelioma of the meninges', Arch. Surg., 1923, 6: 554-72.

35 Julian Taylor, 'Invasion of the skull by dural tumours', Br. J. Surg., 1928, 16: 6-21, p. 6.

${ }^{36}$ Susan Preston-Martin, 'Descriptive epidemiology of primary tumours of the brain, cranial nerves and cranial meninges in Los Angeles County’, Neuroepidemiology, 1989, 8: 283-95, p. 288.
} 